\title{
MIR372 wt Allele
}

National Cancer Institute

\section{Source}

National Cancer Institute. MIR372 wt Allele. NCI Thesaurus. Code C82190.

The human MIR372 wild-type allele is located in the vicinity of 19q13.41 and is approximately 66 bases in length. This allele, which encodes MIR372 pre-miRNA, plays a role in the regulation of gene expression. Alteration in the expression of this gene is associated with development of testicular germ cell tumor and non-small cell lung cancer. 